\title{
A new journal for a new era in neonatology
}

\author{
This article was published in the following Dove Press journal: \\ Research and Reports in Neonatology \\ 3 March 201I \\ Number of times this article has been viewed
}

\section{Robert L Schelonka \\ Oregon Health and Sciences University, Portland, OR, USA}

Correspondence: Robert L Schelonka Associate Professor of Pediatrics, Doernbecher Neonatal Care Center, Oregon Health and Science University, Mail code CDRCP, 707 S.W. Gaines St., Portland, OR 97239-2998, USA

$\mathrm{Tel}+\mathrm{I}$ (503) 494-74I4

Fax + I (503) 494-I542

Emailschelonk@ohsu.edu
The specialty of neonatal medicine is young, only about 50 years old by most accounts. Despite its youth, the magnitude and pace of discovery in our field has been dizzying. Little seems more illustrative of this than considering a 1-kg infant who was born in 1960 had a mortality risk of $95 \%$; however, by the year 2000, a 1-kg infant had a $95 \%$ chance of surviving. ${ }^{1}$ This remarkable progress has been fueled by the fact that clinicians and investigators alike have embraced discovery in our field. I recently searched PubMed under the broad topic of "neonate" and received over half a million hits; the search term "preterm infant" yielded 34,000 hits, and the terms "infection in neonates", a particular research interest of mine, gave 50,000 hits. Given this degree of scholarly activity in our field, one might conclude we have already answered the important questions we face when caring for newborn infants.

A recently published report by the National Institute of Child Health and Human Development (NICHD) Neonatal Research Network suggests there is still important work to be done in our field. This network of 20 US academic neonatal intensive care units reported that many important outcome measures, including survival of infants at borderline viability, have not changed appreciably in the last decade. ${ }^{2}$ Does this plateau in survival rates for the tiniest of infants mean we have reached a new survivor threshold? Equally alarming was a recent report of a large cohort showing early-childhood neurodevelopmental outcomes do not seem to be improving for infants born at $<25$ weeks' gestational age. ${ }^{3}$

The challenges we face in neonatology for the next 50 years are many. How can we better understand the etiopathogenesis of necrotizing enterocolitis and white matter injury to the brain, which have largely been elusive to date, to develop strategies preventing the devastating consequences from these diseases? How can we better understand the developing immune system of the fetus and newborn to target specific (relative) immune deficiencies and develop tools to enhance immune function with the goal of preventing infections, the single most important cause of death in newborns? Can we learn more about the unique nutritional needs of tiny newborn infants to feed and fortify their feedings to promote optimal development of the brain and body while avoiding "metabolic conditioning" that programs the development of certain "adult" diseases? How do we improve survival without neurosensory impairment of the tiniest infants? How do we care for and meet special needs the families of our patients face during a prolonged hospitalization? How can we assure high quality follow-up, early intervention and opportunities for these infants to mature to their fullest potential after 
leaving our care? How do we work with systems and teams for quality improvement? How can we improve neonatal outcomes in regions with limited medical resources?

I believe the key to moving ahead in the new era of neonatal medicine is the interchange of ideas and data from observational studies and clinical trials. The new journal new journal titled Research and Reports in Neonatology is an open access venue to share commentary, reviews, and original research. I believe this new venue will be a mechanism to meet Dr Stoll's recent challenge to identify and test interventions and resources that yield consistently lower morbidity and mortality rates at some centers, so that we can improve rates of survival without major morbidities and reduce longterm neurodevelopmental impairments for all infants. ${ }^{2}$ The underlying goal of Research and Reports in Neonatology is to freely share and encourage objective evaluation of our experiences and discoveries in the understanding of diseases as well as the care of these fragile newborn infants. I thank the members of our editorial board, reviewers, authors, and Dove Medical Press for their tremendous help in preparing this inaugural issue.

\section{References}

1. Philip AG. The evolution of neonatology. Pediatr Res. 2005;58(4): 799-815.

2. Stoll BJ, Hansen NI, Bell EF, Shankaran S, Laptook AR, Walsh MC, et al. Neonatal outcomes of extremely preterm infants from the NICHD Neonatal Research Network. Pediatrics. 2010;126(3): 443-456.

3. Hintz SR, Kendrick DE, Wilson-Costello DE, Das A, Bell EF, Vohr BR, et al. Early-childhood neurodevelopmental outcomes are not improving for infants born at $<25$ weeks' gestational age. Pediatrics. 2011;127(1):62-70.

\section{Publish your work in this journal}

Research and Reports in Neonatology is an international, peer-reviewed, open access journal publishing original research, reports, editorials, reviews and commentaries on neonatal health. The manuscript management system is completely online and includes a very quick and fair peer-review system. Visit http://www.dovepress.com/testimonials.php to read real quotes from published authors. 